\title{
Private consultants, planning reform, and the marketisation of local government finance
}

Mike Raco, Bartlett School of Planning, UCL

\section{Chapter 8 in Ferm, J. and Tomaney, J. [eds.] Planning Practice - Critical Perspectives from the UK}

\section{Introduction}

This chapter examines the ways in which planning systems across the UK are being systematically reshaped by the twin processes of privatisation and the marketisation of local government finance. It argues that local planning arrangements are being re-fashioned into a growth-led, entrepreneurial mode of governance, designed to maximise financial returns for public and private interests and use planning 'gain' to pay for broader welfare interventions. This systematic entrepreneurialisation of local government means that it no longer fulfils its traditional post-war role of acting as a local provider of national welfare programmes, dependent on the re-distribution of centrally allocated funds (see Cochrane, 1993). In its place, local authority planners and planning authorities are being converted into spear-heads for a wider governmental programme that prioritises the delivery of growth in the UK's cities and regions. In some instances, as will be discussed below, councils have even become active development agents themselves and established public-private partnerships in an increasingly desperate effort to mitigate the impacts of central government austerity cuts. All of this has taken place in a context of growing social and spatial inequalities, fluctuating and unpredictable welfare demands from increasingly diverse communities, growing pressures on local welfare services 
brought about by ageing populations, and the constant threat of major governmental shocks, such as the effects of Brexit, de-globalisation, and/or another financial crash (see Dorling, 2014).

The chapter will show how the entrepreneurialisation of planning has gone hand-in-hand with fundamental changes in the organisation and management of the UK state. Across the world governments have undertaken privatisation programmes since the early 1980s as they wrestle with growing fiscal constraints and increasing welfare demands (see Streeck, 2016). Across the UK the planning system is increasingly subject to processes of privatisation with private experts becoming active players in the shaping of key policy regulations and outcomes. This, the chapter will argue, has powerful, yet under-researched, implications for understandings of planning practice. Much of the planning literature is still underpinned by assumptions over, for example, the primacy of public planners and/or definitions of a public interest and has been slow to realise just how significant a change is taking place in how local planning governance is operating. As will be shown, it is increasingly difficult to identify what constitutes a 'public' or 'private' actor and the chapter concurs with Moore (2012) who argues that 'what is of greater significance than the question of what is public and what is private is how and why the dichotomy is normalised and perpetuated in different contexts of development and planning' (p.593).

The discussion is divided into three sections. The first examines the changing nature of local government finances and the extent of austerity cuts. It argues that a new centralised localism in financial models is being implemented that aims to promote local financial 'self-sufficiency' and the privileging of economic development priorities. The second section examines evidence on the growth of private consultancies and recent changes in the sector. It reviews published information on the 
scale and character of the consultancy sector and draws on the analysis of company documents and strategies to examine how it is changing in the wake of recent reforms. A final section then interrogates the implications of these trends for the future of planning practices and identifies some of the limitations inherent in recent reforms. It discusses the possibilities for the development of alternative forms of local planning practice and aspects of what this might consist of.

\section{Austerity urbanism and the growth of a New Entrepreneurialism}

The effects of the financial crisis of 2008 , and the implementation of austerity budgets by successive governments since 2010, have had a major impact on the capacities and structures of the UK's planning systems. Under the Coalition (2010-2015) and subsequent Conservative administrations (2015-present), a political project of austerity has been rolled out, premised on the assumption that state bureaucracies had become 'too big' and that a new politics of less top-down and centralist statecraft was required. Reform agendas continue fuelled by visions of an on-going economic 'emergency' precipitated by the events of 2008 and the perceived need to use state systems and services to generate, where possible, new sources of finance and income (see Wolin, 2008). For former Prime Minister David Cameron (2011), this involved "put[ting] in place principles that will signal the decisive end of the old-fashioned, top-down, take what you're given model of public services. And it is a vital part of our mission to dismantle big government" (p.1). In order to achieve this end the government enshrined in law a "a new presumption - backed up by new rights for public service users and a new system of independent adjudication - that public services should be open to a range of providers competing to offer a better service" (p.1). 
The practical implications of this approach have been profound both on local government and the planning system it regulates and oversees. Local authority budgets in England have been cut by $£ 18$ billion since 2010 with the burden falling disproportionately on areas of greatest social and economic need. As The Economist (2017) notes 'since 2010 the third of councils that are most dependent on Whitehall [for funding] have had to cut their spending on services by an average of $33 \%$, while the tenth that are least dependent have made cuts of only $9 \%$ ' (p.1). Within this broader picture spending on local authority Planning and Development services has fallen from £2.197billion in 2010 to $£ 1.652$ in $2011 / 2012$ and a new low of $£ 1.059$ billion in $2016 / 2017$, an unprecedented reduction of over $50 \%$ in just six years ${ }^{\mathrm{i}}$. Treasury figures for $2016 / 17$ show a further $8 \%$ cut to come, relative to total budget reductions for local government of only $1 \%$ (DCLG, 2016: p.4). In other parts of the UK cuts to local government have been less severe but still significant. Between 2010/11 and $2017 / 18$ central grants to Scottish local authorities will have fallen by $9.2 \%$ from $£ 10.5$ billion to $£ 9.5$ billion at a time of growing demand on services (Accounts Commission, 2017). In Wales overall budget cuts have been limited to 2.5-3\%, but Planning and Development and Housing departments have faced cuts in excess of over 20\% (Crawford et al., 2012). The reasons for these reductions are complex and have resulted from a combination of departmental negotiations amongst civil servants and ministers, a political aversion to the purpose and principles of government-led planning, and relatively little concerted resistance from local government during the early phases of cuts, with few of the public confrontations to cuts that were seen in the $1980 \mathrm{~s}^{\mathrm{ii}}$.

The impacts of resource reductions have been compounded by the mushrooming of statutory regulations under the Labour governments of 1997-2010. Despite the removal of Planning Policy Statements in 2012 and their conversion into a simplified National Planning Policy Framework [NPPF], and the subsequent introduction of the Deregulation Act ${ }^{i i i}$ of 2015, the obligations on local planning authorities continue to be onerous. Recent reforms have introduced significant new 
demands such as the production of binding local plans, the negotiation of planning gain agreements, and clear strategies for land use and development. Local planners therefore have to act with legallybinding 'due diligence' in regard to regulations at the same time as their capacities for action are being seriously eroded by cuts. At the same time, many of the core principles that underpinned local government finance in the post-war period are being systematically replaced by an increasingly competitive set of fiscal regimes in which their ability to maintain their budgets will have to be found through local forms of growth-dependent taxation. As the DCLG (2016:7) states by 2020:

local government will retain $100 \%$ of taxes raised locally. This will give local government additional business rates receipts of around $£ 12.5 \mathrm{bn}$ to spend on local services. The system will have stronger incentives to boost growth, and areas that take bold decisions to boost growth will see the benefits.

The new arrangements form part of a wider set of central government-led reforms in which qualitative modes of practice, such as 'co-operation' and 'partnership-working' have become converted into legalised duties and increasingly quantifiable forms of conduct. The Localism Act 2011, for instance, introduced a new 'legal duty to co-operate... in preparing plans that relate to "strategic matters" (Smith, 2016: p.9). Built into these Plans are a series of requirements that focus on delivery, planning gain, and the viability and profitability of developments for investors and land owners. These are encapsulated in Paragraph 173 of the NPPF, a statement that represents one of the most radical reformulations of planning practice since the Town and Country Planning Act of 1947:

pursuing sustainable development requires careful attention to viability and costs in planmaking and decision-taking. Plans should be deliverable. Therefore, the sites and the scale of development identified in the plan should not be subject to such a scale of obligations and policy burdens that their ability to be developed viably is threatened. 
It goes on to focus on the relationships between the planning system and private developers as,

to ensure viability, the costs of any requirements likely to be applied to development, such as requirements for affordable housing, standards, infrastructure contributions or other requirements should, when taking account of the normal cost of development and mitigation, provide competitive returns to a willing land owner and willing developer to enable the development to be deliverable.

Good planning is elided with expedited decision-making that will ensure that 'pre-commencement planning conditions are only imposed by local planning authorities where they are absolutely necessary' (Smith, 2016b: p.11). Local planners are told that they must contribute to what central government term a 'national crusade' to build thousands of new homes (see Forrest and Hirayama, 2015), whilst reducing the political and socio-economic complexities that exist in local contexts and circumstances. Similar agendas have been rolled out in Scotland in which local authorities are required to draw up Main Issues Reports that identify 'preferred sites' that are 'based on a understanding of place, together with consideration of deliverability factors such as site viability and housing land effectiveness' (Scottish Government, 2013: p.16). Local planners are required to demonstrate a clear "willingness to explore what scope exists to phase the payment of Planning Obligations to assist the development process" and to actively consider "solutions to reduce costs in order to aid viability... and thinking about the scope for revenues to be increased, for example, by increasing the density of the development" (Scottish Government, 2010:2).

The overall trend is for governments across the UK to apply concerted pressure on local actors to give the go-ahead for developments. In England for instance, local authorities have been incentivised to 
build new homes with a New Homes Bonus ${ }^{\text {iv }}$. It is a scheme that has faced implementation difficulties and in the latest round of reforms the government makes it clear that

from 2018/19 we will consider withholding NHB payments from local authorities that are not planning effectively, by making positive decisions on planning applications and delivering housing growth. To encourage more effective local planning we will also consider withholding payments for homes that are built following an appeal (DCLG, 2016b: 9).

This is backed-up by the implementation of a 'national baseline' target for anticipated growth that local authorities will have to meet, whatever local market conditions, in order to receive future payments. The NHB is one of a number of similar carrot and stick approaches to local government finance that are designed to institutionalise entrepreneurial practices at the local level.

The ethos of the planning system is thus inverted. Its traditional role of ensuring that any new development is only granted permission once it conforms to local, publically-defined needs is replaced by a legal requirement, wherever possible, to prioritise growth and the expansion of new homes and development projects. The role of planning practice is to take the messiness and complexity of places and convert them into spaces ripe for investment. The requirement to become financially self-sufficient will make local authorities increasingly dependent on property market uplift, whatever the wider impacts on marginalised local residents, businesses, and places. As Penny (2017) notes, this is leading to a growing correlation between local government in the UK and the entrepreneurial models of 'localism' and growth that have characterised local governance in the United States since the early 20th Century (see also Peck, 2017). 
However, despite this push from the centre, there is growing evidence that cuts to planning budgets are reducing the capacities of the planning system to deliver its growth targets, no matter what the demand (see LGiU and FMB, 2016). Limits on public bureaucracies are being compounded by structural reforms in which local authority services are being compartmentalised and sold off in the name of self-sufficiency. Many local government legal departments, for example, now operate as contracted-out business services to other authorities or private clients, whereas in the past their role was principally to provide advice and guidance to their own authorities (see Dobson, 2014). Some authorities have even embarked on the setting up of Special Purpose Vehicles and, in some instances, become directly involved in profit-making development projects, in order to generate income (see Penny, 2017). It is becoming increasingly difficult for many to meet the expected growth in demands for planning services without turning to the capacities found within the private sector.

The combination of these trends is therefore opening up new markets for private actors. As the next section will demonstrate, there is a direct co-evolution between reforms to make the planning system more entrepreneurial and the emergence of an increasingly powerful and influential consultancy sector that is being tasked to 'fill the gap' left in the wake of public sector retrenchment. New mutually reinforcing arrangements are emerging in which private consultancies provide local authorities with the requisite skills and resources to act more entrepreneurially. Forms of interdependency are emerging in which local authorities become increasingly reliant on the presence of private consultancies in order to function and private firms become increasingly reliant on local government restructuring. The result is that private experts have become increasingly involved in the co-regulation of planning policy reforms and in the day-to-day practices associated with the 
implementation of planning. In the next section the discussion turns to an assessment of key trends in the structure of the planning consultancy sector and its influences.

\section{The Rise and Rise of Planning Consultancies}

The Planning Magazine's extensive Careers and Salaries Survey 2016 of 149 consultancies is the most comprehensive overview of the current state of the planning sector in the UK and key trends in its evolution. It found that $44 \%$ of planners now work in the private sector and that $20 \%$ of remaining public planners are "considering to leave the profession in the next 12 months" (p.3). Professional bodies report a growing trend of low morale, overwork, and lack of resources, with the added incentive that wages and working conditions are perceived to be better in the private sector. As an indication of the degree of change, professional organisations have been re-organising their membership structures, with the RTPI, for example, now possessing a private members network called RTPI Consultants consisting of 465 members. It provides a comprehensive online directory that includes details on core activities, competencies, and staff. The members tend to be from bigger and more established firms, so the RTPI has also set up a small business association named the Independent Consultants Network, geared up to sole practitioners and those who operate their own small practices. In Scotland and Wales these networks are supplemented by public-private liaison groups such as the Scottish Forum for Planning ${ }^{v}$ and the RTPI Cymru's Policy and Research Forum ${ }^{v i}$.

The consultancy sector itself is dynamic and undergoing constant reformation. The diverse market opportunities opened up by recent planning reforms have led to a parallel process of consolidation 
within the sector into bigger companies on the one hand and the simultaneous mushrooming of small firms specialising in specific niche fields of expertise on the other ${ }^{\text {vii }}$ (see Table 8.1). The latter, in turn, are repeatedly acquired by the former who are looking to expand their market strength and their market 'offer' to potential local authority clients. In the period 2006-2015 the multinational Capita, for instance, acquired 130 companies, many of whom specialise in urban planning in different countries, but mainly in the UK. Established, medium-sized specialists are particularly attractive. One recent high profile purchase took place in 2014 when the biggest UK property market player and planning consultancy Savills acquired Smith Gore Ltd. The latter was an established market player that was founded in 1847 and had 532 staff in 31 UK offices. It was attractive to Savills as it specialised in property development planning in rural locations, a sector that the company saw as an area of potential growth but which lacked the specialist skills offered by Smith Gore (see Savills, 2015). Similarly, in 2015 the WYG purchased three established firms, FMW consultancy, Taylor Hardy Ltd., and Signet Planning to create an overall team of 135 experts, making it the $3^{\text {rd }}$ largest UK player. It has since formed a Major Project Unit in an attempt to bring in-house all of the regulatory requirements that public or private sector clients might require. This is part of a wider trend in which there has been a push towards the creation of multi-disciplinary structures within bigger firms, who are then able to offer public sector clients more 'comprehensive' packages of expertise and knowledge.

\section{[Table 8.1: The 10 Largest UK-based Planning Consultancies]}

As with most forms of privatisation, the marketisation of planning has inflated total costs (see Moran, 2015). The Planning Magazine's Survey shows that companies such as Quod charge their clients a rate of $£ 2,850 /$ day and that overall in 2016 " $90 \%$ of firms charge a maximum rate above $£ 800 /$ day and $52 \%$ above $£ 1,200$ ” (p.4). This has increased from respective figures of $69 \%$ and $29 \%$ in 2015 , indicating a rapidly expanding and cost-inflating market for users. The 49 biggest firms reported a total fee income of $£ 498$ million with the main growth areas in advice for activities associated with viability-based planning, such as 'residential planning' and 'brownfield and greenfield planning 
advice, ${ }^{\text {viii. }}$ Major multinationals have become increasingly active players, responding to and helping to shape a growing market with companies such as Capita witnessing "the biggest increases in its Salford and Barnet offices, where it provides planning services on behalf of local authorities", with the possibility that it might soon also "do the same for North Tyneside" (p.15). Capita (2015) state explicitly in their accounts to shareholders that cuts have forced local authorities to become "increasingly commercial and open to exploring new service delivery models" (p.9), from which the company stands to gain. Its single biggest 'business opportunity market' is now the UK public sector, with the most lucrative opportunities emerging in relation to austerity-hit local government and "the ongoing pressure to reduce budgets while maintaining and adapting frontline services" and "increasingly looking to the private sector to find new service solutions...from traditional outsourcing to transformational partnerships" (p.19).

Other major consultancies such as Barton Willmore (2016), similarly tell potential clients that the company "looks to take advantage of UK growth opportunities, particularly when housing numbers expand...as the market eventually responds to the UK's chronic housing need" (p.2). The message is clear; the bigger the housing crisis and the impacts of austerity the bigger the market opportunities for private firms. The dilemma for policy-makers is that by introducing new regulations to establish levers of control over the planning process (such as new health and safety measures or Environmental Impact Assessments), planners and regulators are creating new markets for expert private actors and opening up forms of profit-generation that authors such as Levi-Faur (2011) have termed 'regulatory capitalism', or a process in which the implementation of new codes of regulation open up market opportunities for firms that are best able to co-produce and implement them. A good example of how reforms generate market opportunities is provided by the company Pegasus (2015), one of the UK's largest planning consultancies, that tells its investors (p.2) that,

by employing specialists we can ensure optimal results and outstanding service. With an acute understanding of the changing nature of planning policy at local and national level, we can 
inform and advise clients on the implications of emerging planning and environmental planning policy and offer the most informed and sustainable solutions.

Others such as WYG (2016), whose planning arm made a profit of over $£ 10$ million in 2015, similarly highlight that their expansion had been "driven by strong demand for service across buoyant planning and infrastructure markets" and a "strategy of delivering future growth by obtaining quality revenues from front-end planning" (p.7).

The long-term implications of this growing concentration of power in a relatively small number of major consultancies are likely to be profound. Under the NPPF's viability-based arrangements the (substantial) fees and costs associated with privatisation are recovered by developers/investors through higher property values and future market returns. They form an increasingly important component of negotiations over the subsequent use of land and property. As costs inflate, so the ability of local authorities to impose social obligations on developers becomes more and more limited. There are also spatial implications. Planning practice has traditionally been a local activity, undertaken by local planning authorities who are sensitive to variations in contexts, opportunities, and priorities. However, the market opportunities and returns to be found in bigger cities, with thriving property development programmes, is encouraging private firms to gravitate their focus of attention towards major centres, with less interest in areas in which markets are less lucrative. There is already some evidence of major firms concentrating their activities, and establishing a presence, in major centres of 'opportunity'.

The gradual entrepreneurialisation of planning also has implications for territorial competition and patterns of spatial development. The expansion of private expertise is encouraging a competitive growth politics. In Scotland, for example, the Scottish Property Federation, amongst others, are increasingly drawing on comparative data between different cities and the UK's nations to push for a 
further stream-lining and speeding up of the planning process 'if we are to attract and retain global capital to support local jobs and investment' (Melhuish, 2016: p.3). Edinburgh City, in particular, is criticised for its relatively slow approvals process ${ }^{\mathrm{ix}}$. The experiences and conditions found in areas of growth are becoming norms of 'best practice' that influence the activities of planning authorities operating under very different market conditions. As Colenutt et al. (2015) have shown, the standard viability 'bench-mark' for private sector profits used in negotiations is often set at an approximate rate of $20 \%$, a figure based on the specific experiences of escalating property prices in London and the South East. Reliance on external experts and consultants, when allied to central government directives, will inevitably reduce the 'localness' of planning decisions.

The tendency to increase fees in the private sector shows little sign of abating. Firm accounts and statements repeatedly show that skills shortages are now hampering expansion plans and generating a fierce competition for workers that, in turn, is further pushing up labour costs and fees, whilst also encouraging further acquisitions. Moreover, as with any field of private practice, there are also wide variations in the ethical outlooks of market players. Since 2012, a new sector has emerged in which consultancies provide expert help to developers to help them reduce their social obligations. Companies such as S106-Management (2016) market themselves as specialists in reducing the social benefits provided by the planning system:

If the profit margin for your scheme is pushed to below $17.5 \%$ by Affordable Housing or other Section 106 payments, we can help. The demands made by local planning authorities should not jeopardise the viability of any underlying planning permission. In these cases we can prepare a Viability Assessment based on properly documented building costs and sales values, helping you to negotiate a significant reduction in your Affordable Housing provision or Section 106 payments (p.1). 
They provide examples in which their expertise was used to help developers maximise the building of expensive apartments. In Bexley, London, their assessments helped to 'prove' that the local authority's requirements for $35 \%$ to be affordable lacked viability, thereby saving the developer $£ 193,853$ in social obligations (see: http://www.section-106.co.uk/case-studies). In 2016 the site, a former pub, and planning permission for 10 apartments (only one of which has more than two bedrooms for a family), was on sale for "offers in excess of $£ 1$ million” (see Caldecott Group, 2016). As market opportunities expand, so inevitably will the presence and influence of such firms.

\section{Where Next for Planning Practice?}

The chapter has argued that the very ethos of what the planning system is for and what it should do have been re-imagined and remade in the wake of austerity cuts and the introduction of viability planning regimes. As Peck (2017) notes, such processes represent the extension of a 'late entrepreneurial' mode of local governance, in which local authorities take on new financial risks and activities to maintain their income streams. The introduction of such systems across the UK is truly radical. This situation differs from earlier rounds of property-led urban policy in which well-resourced public bodies, such as Urban or New Town Development Corporations, were set up to promote property development and use market returns to help fund their key infrastructure. In a context of austerity, local authorities increasingly rely on such returns to undertake their basic statutory social duties, making their room for manoeuvre and their ability to promote integrated infrastructures for development all the more limited. This dependency means that planning practices have become intricately bound-up with the unpredictability of market conditions and broader shifts in forms of capital investment away from productive uses and into property and rental markets (see Standing, 2016). 
Greater reliance on planning gain is also limiting the possibilities for non-market forms of intervention and the types of local programmes that planners have traditionally undertaken, such as the acquisition of land for community uses or the provision of subsidised incubator sites for local entrepreneurs. Innovative activities, such as the re-use or intensification of existing infrastructure, have become less attractive as their levels of viability tend to be lower than those of new build programmes. This means that the traditional skills and knowledge(s) that underpinned the practices of post-war planners, such as the ability to negotiate between private and public interests, whilst maintaining a strategic overview of place development, look increasingly out-dated. They still haunt contemporary policy imaginations and discussions over the supposedly 'bureaucratic' nature of planning, but as the chapter has argued these are of less and less significance. In their place the skills to support contemporary planning practices are now to be found in the fields of contract negotiations, the use of good governance templates, the specification of quantifiable inputs and outcomes, and the empowerment of a new generation of technocratic experts. The capacity to negotiate a 'good contract' with a private developer has taken on a new primacy within local authorities, many of whom are now themselves looking for expert help from private consultants.

However, it should also be noted that all models of governance are prone to failures and political challenges. High-profile 'failures' in private provision in sectors such as public transport or the utilities might give a new legitimacy to calls for enhanced public sector control. Some local authorities have also brought in innovative programmes to re-use public assets. In the London boroughs of Islington and Camden planners have introduced new models for the delivery of affordable housing that are more exacting on private developers and make full use of their negotiating powers. On a global scale there exist multiple models of local government practice and financial management that could also be adopted in the UK context. For example, in some parts of Europe and 
Latin America there have been strong moves towards the 're-municipalisation' of services and infrastructure, particularly in contexts in which private providers are perceived to have 'failed' to maintain or deliver on their contracted obligations (see Hall et al., 2013; Pigeon, 2017). There are ongoing calls from some for the re-municipalisation of public housing and planning policy in the context of governmental shocks, such as Brexit or a new financial crisis, the conditions within which viability planning currently operates may change significantly, necessitating new policy fixes and imaginations (see Shelter, 2017).

At the same time the growing inter-dependencies between both local authorities and the consultancy sector presents new risks and vulnerabilities for all parties. A market crash would leave local authorities with under-priced assets and liabilities, exposing them to the risk of bankruptcy (see Wilby, 2017). The early signs are that new arrangements will entrench existing inequalities between places but this may, in turn, generate political pressure for reform. Resistance to some of the proposed changes is being mobilised by Conservative-controlled local authorities and the Conservative Party-dominated Local Government Association, as well as at the national level by different political parties. There is much scope for the alteration and amendment of current reforms and proposals. The chapter has argued, however, that the co-evolution of planning reforms and a growing consultancy sector is establishing a powerful dynamic that will take significant political will to re-shape in future.

\section{Acknowledgements}


The author wishes to thanks Dr Ed Jones for his assistance in compiling materials for this chapter and to Jess Ferm and John Tomaney for comments on the first draft. Thanks also to Sonia Freire-Trigo, Tatiana Moreira de Souza, Joe Penny and Ed at the Bartlett School of Planning for sharing and discussing their stimulating work and insights on contemporary local government reform. Responsibility for the final draft is, of course, the author's alone.

\section{References}

Accounts Commission (2017) Local government in Scotland - Performance and challenges 2017, Edinburgh: Accounts Commission.

Barton Willmore (2016) Consolidated group financial statements 2016, London: Companies House.

Caldecotte Group (2016) 'Former Fanny on the Hill Public House Freehold’; accessed at: https://media.realla.co/uploads/property/brochures/original/sujFnX0_qDTuNSmw-aYpDw, 13 January 2017.

Cameron, D. (2011) 'Cameron unveils privatisation drive', speech quoted in: http://m.hsj.co.uk/5026022.article, accessed 10 February 2015.

Capita (2015) Annual report and accounts 2015, London: Companies House.

Cochrane, A. (1993) Whatever happened to local government? Milton Keynes: Open University Press. 
Colenutt, B., Cochrane, A., and Field, M. (2015) The rise and rise of viability assessment, Town and Country Planning, (84) 453-458.

DCLG (2016a) The provisional 2017-18 local government finance settlement: confirming the offer to councils, London: HMSO.

DCLG (2016b) New Homes Bonus: Sharpening the incentive, London: HMSO.

Dobson, N. (2014) 'What are local authority legal departments for?', available at:

https://www.localgovernmentlawyer.co.uk/index.php?option=com_content\&view=article\&id=18804 \%3Awhat-are-local-authority-legal-departments-for\&catid=50\&Itemid=10, accessed 21 December 2016.

Dorling, D. (2014) Inequality and the One Percent, London: Verso.

[The] Economist (2017) 'Running on empty - Local councils' finances are in a parlours state', January 28 th.

Forrest, R. and Hirayama, Y. (2015) The financialisation of the social project: Embedded liberalism, neoliberalism and home ownership, Urban Studies, (52) 233-244.

Hall, D., Lobina, E. and Terhorst, P. (2013) Re-municipalisation in the early 21st century: Water in France and energy in Germany, International Review of Applied Economics, (27) pp.193-214. 
Levi-Faur, D. (2011) From big government to big governance, Jerusalem Papers in Regulation \& Governance, Working Paper No.35, Jerusalem.

Local Government information Unit [LGiU] and Federation of Master Builders [FMB] (2016) Small is beautiful - Delivering more homes through small sites, London: LGiU.

Melhuish, D. (2016) Foreword, Annual Planning Survey 2016, Edinburgh: GL Hearn and Scottish Property Federation.

Moore, S. (2012) Re-evaluating public and private in local development cultures: Converging vocabularies of public good and market success in Toronto's new urbanism, Town Planning Review, (35), pp.576-595.

Moran, M. (2015) Politics and governance in the UK, London: Palgrave.

Peck, J. (2017) Transatalantic city part 1: Conjunctural urbanism, Urban Studies. Accessed at: http://journals.sagepub.com/doi/abs/10.1177/0042098016679355

Pegasus (2015) Annual report and accounts, 2014-2015, London: Companies House.

Penny, J. (2017) Between coercion and consent: The politics of cooperative governance at a time of austerity localism in London, Urban Geography. Accessed at:

http://dx.doi.org/10.1080/02723638.2016.1235932 
Pigeon, M. (2017) 'Une eau ', accessed at: publique pour Paris: Symbolism and success in the heartland of private water', accessed at:

http://www.municipalservicesproject.org/sites/municipalservicesproject.org/files/uploadsfile/remunici palisation-chap2-Paris.pdf, 7 March 2017.

S-106 Management (2016) 'Looking to Avoid Providing Affordable Housing?' accessed at: http://www.section-106.co.uk/?gclid=CJGV69mdv9ECFcIp0wodKqEMBA, 13 January 2017.

Savills Plc. (2015) ‘Proposed acquisition of Smiths Gore', accessed at:

http://www.savills.co.uk/_news/article/55328/187730-0/4/2015/proposed-acquisition-of-smiths-gore, January 132017.

Scottish Government (2010) ‘Development Viability Factsheet’, Edinburgh: Scottish Government.

Scottish Government (2013) Development Planning, Edinburgh: Scottish Government.

Shelter (2017) Why we need more social housing in England, accessed at:

http://england.shelter.org.uk/campaigns_/why_we_campaign/Improving_social_housing/Why_we_ne ed_more_social_housing, 7 March 2017.

Smith, L. (2016) Planning for housing - Briefing Paper No. 03741, House of Commons Library, London: HMSO.

Standing, G. (2016) The corruption of capitalism - Why rentiers thrive and work does not pay, London: Biteback Books. 
Stoker, G. (1991) The politics of local government, Basingstoke: Macmillan.

Streeck, W. (2015) How will capitalism end?, Cambridge: Polity Press.

Wilby, P. (2017) Councils are facing bankruptcy - is this the end of public service, accessed at:

https://www.theguardian.com/commentisfree/2017/mar/06/councils-local-authorities-bankruptcy-

public-service?, 8 March 2017.

Wolin, S. (2008) Democracy incorporated, Princeton: Princeton University Press.

WYG (2016) Annual Report and Accounts 2016, London: Companies House.

\footnotetext{
${ }^{\mathrm{i}}$ Figures taken from Department of Communities and Local Government (2013) Statistical Release 24 September 2013 Local Authority Revenue Expenditure and Financing England 2011-12 final outturn (revised), HMSO, London and Department of Communities and Local Government (2014) Local Authority Revenue Expenditure and Financing: 2016-17 Budget, England, HMSO, London.
}

ii During the 1980s some local authorities acted as the principal sites of resistance to the then Thatcher government's monetarist programmes of reform. Some of the most radical (urban) authorities were eventually abolished by central government (see Cochrane, 1993).

iii The Deregulation Act 2015 abolished some of local government's planning functions, most notably the previous duty to prepare Sustainable Community Strategies and the requirement to create Local Area Agreements and Multi-area Agreements. All were high-profile Labour government interventions.

iv 'The New Homes Bonus was introduced by the Coalition Government with the aim of encouraging local authorities to grant planning permissions for the building of new houses in return for additional revenue. Under the scheme, the Government matches the Council Tax raised on each new home built for a period of 6 years. Local authorities are not obliged to use the Bonus funding for housing development' (House of Commons Library, 2016:p.1, accessed at: http://researchbriefings.parliament.uk/ResearchBriefing/Summary/SN05724).

v The Scottish Forum for Planning officially 'aims to bring together key interests and expertise in planning to: Provide an ongoing vision and direction for planning in Scotland through identifying, constructively responding to, and exploring new ways of tackling, emerging issues in planning: Support the delivery of planning reform and performance improvement: Share information activity to maximise joint working and minimise duplication' see: http://www.rtpi.org.uk/the-rtpi-nearyou/rtpi-scotland/networks-and-forums/scottish-forum-for-planning/

\footnotetext{
vi The Forum 'leads on RTPI Cymru policy, practice and research activities and comprises representatives from across Wales with experience in a variety of planning topics', see: http://www.rtpi.org.uk/the-rtpi-near-you/rtpi-cymru/policy-inwales/policy-and-research-forum/.

${ }^{\text {vii }}$ Small firms are sometimes established by individuals who have left local authority planning departments or major companies.

viii There is also evidence of market consolidation with the top 10 fee earners alone reporting a total income of $£ 373$ million, up from $£ 345$ million the previous year.
} 
ix The Press Release associated with the report is entitled 'Scottish planning system trailing behind the rest of the UK', see: http://www.glhearn.com/aboutus/Pages/NewsArticle.aspx?article=256 